\title{
Pepper Weevil, Anthonomus eugenii Cano (Insecta: Coleoptera: Curculionidae) ${ }^{1}$
}

John L. Capinera ${ }^{2}$

The pepper weevil, Anthonomus eugenii Cano, is the most important insect pest of pepper in the southern United States.

\section{Distribution}

The origin of the pepper weevil likely is Mexico, though it has spread throughout most of Central America and the Caribbean, and to the southern USA. Pepper weevil was first found in the United States in Texas, in 1904, reaching California in 1923 and Florida in 1935. It is now found across the southernmost United States from Florida to California. Pepper weevil populations persist only where food plants are available throughout the year, largely limiting its economic pest status to the southernmost state in the USA. Because transplants are shipped northward each spring, however, pepper weevil sometimes occurs in more northern locations. Pepper weevil was first observed in Hawaii in 1933 and in Puerto Rico in 1982.

\section{Life Cycle and Description}

A complete generation requires 20 to 30 days, depending on weather. Under insectary conditions in California, up to eight generations have been produced in a single year, but three to five generations is probably normal in most locations. The adults are long-lived and produce overlapping generations, so it is difficult to ascertain generation number accurately. In central Florida, adults are common from March until June, reflecting the availability of peppers, but a few can be found throughout the year except in December and January. Adults overwinter, but only where food is available, because diapause does not occur in this species.

Egg. Oviposition may commence within two days of mating. The eggs are white when first deposited, but soon turn yellow. They are oval in shape and measure $0.53 \mathrm{~mm}$ in length and $0.39 \mathrm{~mm}$ in width. Eggs are deposited singly beneath the surface of the bud or pod. The female creates an egg cavity with her mouthparts before depositing the egg, and seals the puncture containing the egg with a light brown fluid that hardens and darkens. Females

1. This document is EENY-278, one of a series of Featured Creatures from the Entomology and Nematology Department, Florida Cooperative Extension Service, Institute of Food and Agricultural Sciences, University of Florida. Published: November 2002. This document is also available on Featured Creatures Website at http://creatures.ifas.ufl.edu. Please visit the EDIS Website at http://edis.ifas.ufl.edu.

2. John L. Capinera, professor/chairman, Entomology and Nematology Department, Institute of Food and Agricultural Sciences, University of Florida, Gainesville, FL 32611.

The Institute of Food and Agricultural Sciences (IFAS) is an Equal Employment Opportunity - Affirmative Action Employer authorized to provide research, educational information and other services only to individuals and institutions that function without regard to race, creed, color, religion, age, disability, sex, sexual orientation, marital status, national origin, political opinions or affiliations. For information on obtaining other extension publications, contact your county Cooperative Extension Service office. Florida Cooperative Extension Service / Institute of Food and Agricultural Sciences / University of Florida / Larry R. Arrington, Interim Dean 
deposit eggs at a rate of about five to seven eggs per day, and fecundity averages 341 eggs but is nearly 600 in some individuals. The mean incubation period is 4.3 days, with a range of three to five days.

Larva. There are three instars. The larvae are white to gray in color, with a yellowish brown head. They lack thoracic legs and have few large hairs or bristles. Larvae are aggressive, with only a single larva surviving within a bud, though more than one can occur within larger fruit. First instars measure about $1 \mathrm{~mm}$ in length (range $0.8-1.5 \mathrm{~mm}$ ). Second instars measure about $1.9 \mathrm{~mm}$ in length (range 1.3 to $2.6 \mathrm{~mm}$ ). Third instars measure about $3.3 \mathrm{~mm}$ (range 2.2 to $5.0 \mathrm{~mm}$ ). Mean development time of the larvae is about 1.7, 2.2, and 8.4 days for instars 1, 2 and 3, respectively. The figure for third instar development time contains a prepupal period of about 4.9 days, during which the larva creates a pupal cell from anal secretions.

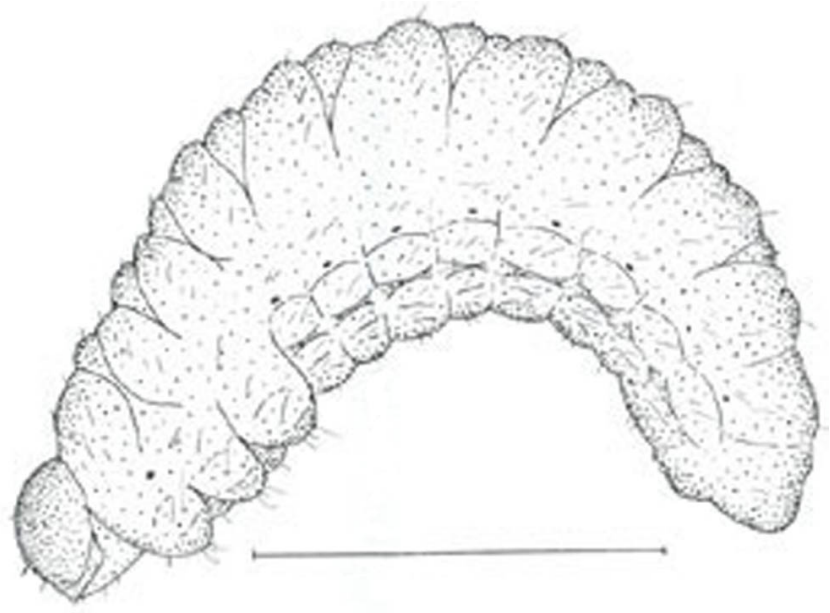

Figure 1. Larva. Line $=2 \mathrm{~mm}$. Credits: John L. Capinera, University of Florida

Pupa. The pupal cell is brittle and found within the blossom or fruit. The pupa resembles the adult in form, except that the wings are not fully developed and large setae are found on the prothorax and abdomen. The pupa is white when first formed, but eventually becomes yellowish with brown eyes. Mean duration of the pupal stage is 4.7 days (range three to six days).

Adult. The adult emerges from the pupal case three to four days after being formed. A clean, round hole marks the escape of the beetle from the bud or fruit. The blackish beetle is oval in shape and varies

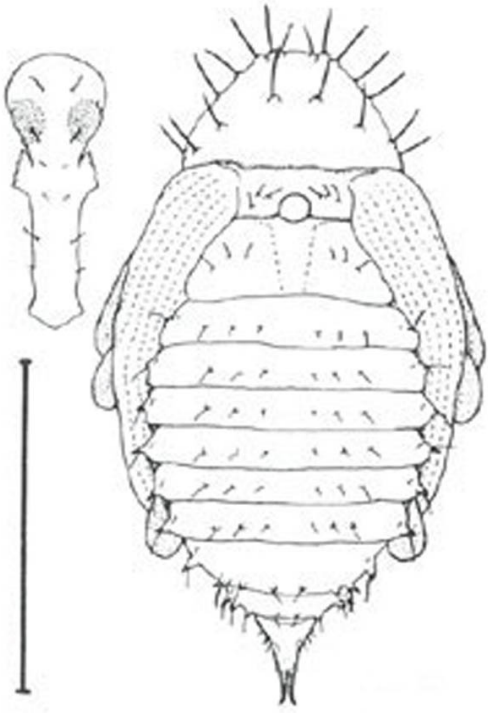

Figure 2. Dorsal view of pupa with head and rostrum shown in ventral view. Line $=2 \mathrm{~mm}$. Credits: John L. Capinera, University of Florida

from 2.0 to $3.5 \mathrm{~mm}$ in length and 1.5 to $1.8 \mathrm{~mm}$ in width. The body is strongly arched and with a long, stout beak as is typical for this genus. The thorax and elytra are mostly covered with small scales. The antennae are long and markedly expanded at the tip. The femora each bear a sharp tooth. The color is dark mahogany to nearly black. Feeding begins immediately after emergence. Males produce an aggregation pheromone that attracts both sexes (Eller et al.).

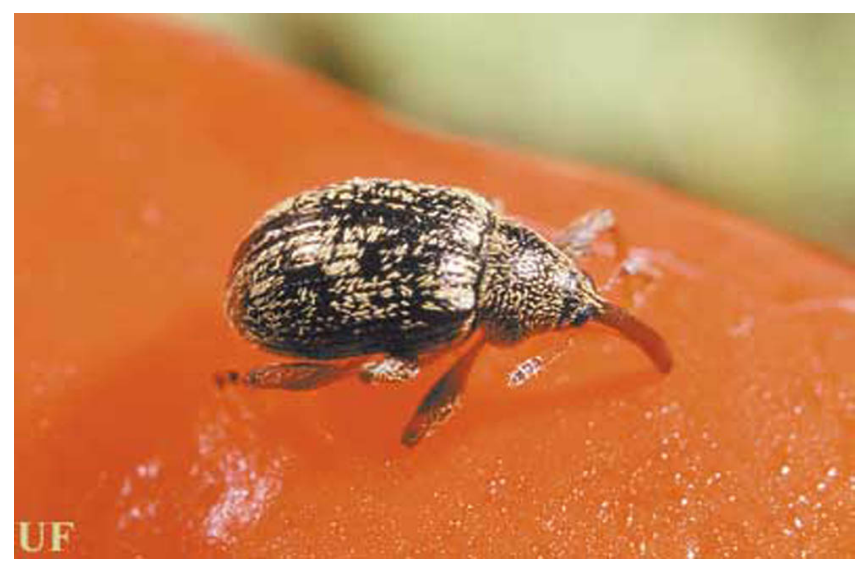

Figure 3. Adult pepper weevil, Anthonomus eugenii Cano. Credits: John L. Capinera, University of Florida

The most complete treatment of pepper weevil biology is given by Elmore et al. (1934). Other descriptions are by Goff and Wilson (1937) and Gordon and Armstrong (1990). Host relations are described by Patrock and Schuster (1992). 


\section{Host Plants}

Pepper weevil larvae develop only plants in the family Solanaceae. Oviposition occurs on plants in the genera Capsicum and Solanum, but feeding by adults extends to other Solanaceae such as Physalis, Lycopersicon, Datura, Petunia, and Nicotiana. Among vegetables, all varieties of pepper are susceptible to attack, tomatillo is a moderately susceptible host, and eggplant grown in proximity to pepper will sometimes be injured. Several species of nightshade support pepper weevil, particularly black nightshade, Solanum nigrum, but also silverleaf nightshade, S. elaeagnifolium; horsenettle, $S$. carolinense; buffalo bur, $S$. rostratum; and Jerusalem cherry, S. pseudocapsicum.

\section{Damage}

An important form of damage is destruction of blossom buds and immature pods. Both adult and larval feeding causes bud drop. Adult feeding punctures appear as dark specks on the fruit, and are not very damaging. Sometimes the fruit is deformed. Fruit drop is very common, and is perhaps the most obvious sign of infestation. Larval feeding within the mature pod is another important form of damage, causing the core to become brown, and often moldy. The stem of pods infested by larvae turn yellow, and the pod turns yellow or red prematurely. In the absence of pepper blossom and fruit, adults feed on leaves and stem material of pepper, but cause no significant damage by these habits. Puncture of peppers by pepper weevil allows penetration of the fungus Alternaria alternata, an otherwise weak pathogen, and extensive fungal growth within the pepper fruit.

In some areas of southern Florida another weevil is found affecting pepper, Faustinus cubae (Boheman). This weevil, though a serious pest in Brazil and other areas of Latin America, is still quite limited in distribution in the United States. It can be a serious pest where it occurs. The larvae, which are similar in appearance to Anthonomus euginii, bore in the stems of pepper and related plants, sometimes entering the fruit. Thus, the larvae are easily confused. The appearance of adults is distinct, however, with the body of the $F$. cubae weevil

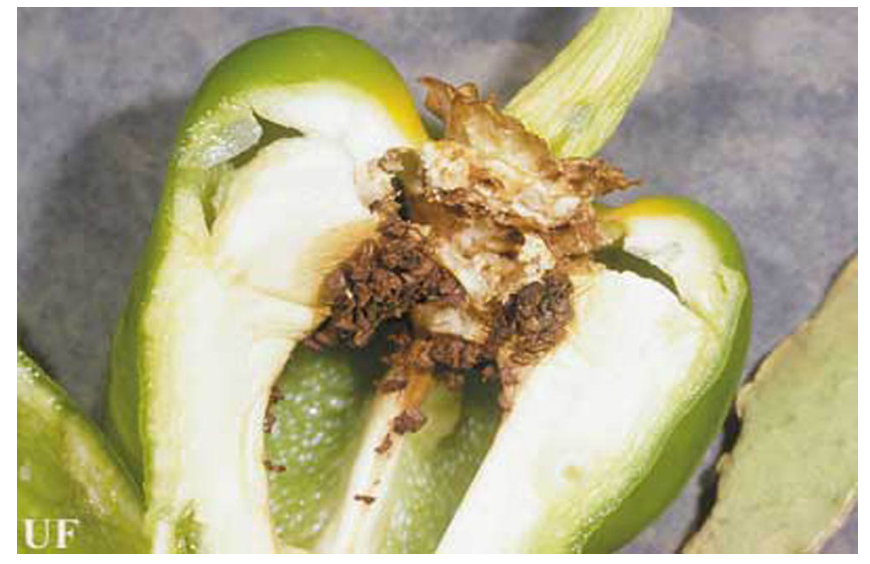

Figure 4. Feeding damage in pepper caused by pepper weevil larvae of Anthonomus eugenii Cano. Credits: John L. Capinera, University of Florida

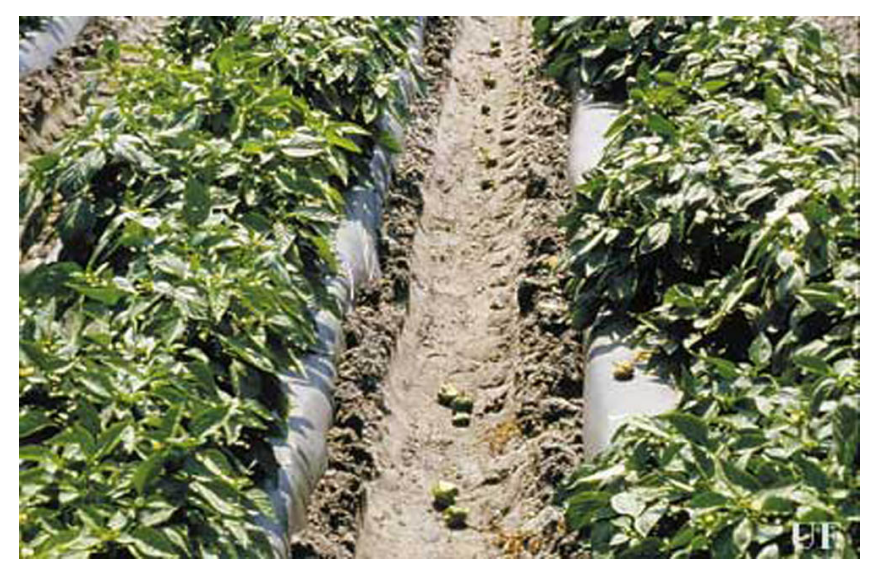

Figure 5. Pepper drop in the field; a common sign of infestation by the pepper weevil, Anthonomus eugenii Cano. Credits: John L. Capinera, University of Florida

bearing numerous rough or raised areas, and a considerable amount of brown coloration. This is in sharp contrast to the shiny black A. eugenii.

\section{Natural Enemies}

Parasitoids of pepper weevil include Catolaccus hunteri Crawford (Hymenoptera: Pteromalidae) and Bracon mellitor Say (Hymenoptera: Braconidae). Riley and Schuster (1992) reported up to $26 \%$ parasitism of pepper weevil larvae by $C$. hunteri.

\section{Management}

Sampling. The distribution of weevils is aggregated. Adult population estimates are best obtained by visual examination and yellow sticky traps (Segarra-Carmona and Pantoja 1988a). Traps should be placed 10 to $60 \mathrm{~cm}$ above the soil; one 375 $\mathrm{sq} \mathrm{cm}$ trap captures as many weevils as are detected 
by inspecting 50 buds (Riley and Schuster 1994). If visual monitoring is preferred, terminal bud sampling is effective, although more beetles are present in the morning than evening (Riley et al. 1992a). Action thresholds of one adult per 400 terminal buds (Riley et al. 1992b) or $1 \%$ of buds infested (Cartwright et al.) have been suggested. A sequential sampling protocol was developed by Segarra-Carmona and Pantoja (1988b).

Insecticides. Insecticides are commonly applied to the foliage at short intervals once buds begin to form. Insecticidal suppression is feasible, but insecticides vary considerably in effectiveness, and even in the presence of chemical insecticides some loss commonly occurs. Segarra-Carmona and Pantoja (1988b) estimated that economic damage commences with adult populations of 0.01 beetle per plant.

For more management information see, Insect Management Guide for Tomatoes, Peppers and Eggplant (http://edis.ifas.ufl.edu/IN169).

Cultural practices. There are few cultural practices that significantly affect pepper weevil damage. Berdegue et al. (1994), working in Texas, compared 35 varieties of jalapeno, bell, pimento, serrano, yellow, cayenne, chile, tabasco and cherry peppers, and found few differences in susceptibility. Sanitation can be important, if it can be implemented on an appropriate scale. Removal and destruction of fallen fruit, for example, will result in destruction of larvae and pupae. Similarly, a crop-free period, if accompanied by destruction of alternate hosts, can disrupt the life cycle. It is very important to eliminate wild solanaceous host plants if pepper weevil is to be managed efffectively.

\section{Selected References}

Berdegue M, Harris MK, Riley DW, Villalon B. 1994. Host plant resistance on pepper to the pepper weevil, Anthonomus eugenii Cano. Southwestern Entomologist 19:265-271.

Cartwright B, Teague TG, Chandler LD, Edelson JV, Bentsen G. 1990. An action threshold for management of the pepper weevil (Coleoptera: Curculionidae) on bell peppers. Journal of Economic Entomology 83:2003-2007.
Eller FJ, Bartelt RJ, Shasha BS, Schuster DJ, Riley DG, Stansly PA, Mueller TF, Shuler KD, Johnson B, Davis JH, Sutherland CA. 1994. Aggregation pheromone for the pepper weevil, Anthonomus eugenii Cano (Coleoptera: Curculionidae): identification and field activity. Journal of Chemical Ecology 20:1537-1555.

Elmore JC, Davis AC, Campbell RE. 1934. The pepper weevil. U.S. Department of Agriculture Technical Bulletin 447. 25 pp.

Goff CC, Wilson JW. 1937. The pepper weevil. Florida Agricultural Experiment Station Bulletin 310. $12 \mathrm{pp}$.

Gordon R, Armstrong AM. 1990. Biologia del picudo del pimiento, Anthonomus eugenii, Cano (Coleoptera: Curculionidae), en Puerto Rico. Journal of Agriculture, University of Puerto Rico 74:69-73.

Patrock RJ, Schuster DJ. 1992. Feeding, oviposition and development of the pepper weevil, (Anthonomus eugenii Cano), on selected species of Solanaceae. Tropical Pest Management 38:65-69.

Riley DG, Schuster DJ, Barfield CS. 1992a. Sampling and dispersion of pepper weevil (Coleoptera: Curculionidae) adults. Environmental Entomology 21:1013-1021.

Riley DG, Schuster DJ, Barfield CS. 1992b. Refined action threshold for pepper weevil adults (Coleoptera: Curculionidae) in bell peppers. Journal of Economic Entomology 85:1919-1925.

Riley DG, Schuster DJ. 1992. The occurrence of Catolaccus hunteri, a parasitoid of Anthonomus eugenii, in insecticide treated bell pepper. Southwestern Entomologist 17:71-72.

Riley DG, Schuster DJ. 1994. Pepper weevil adult response to colored sticky traps in pepper fields. Southwestern Entomologist 19:93-107.

Segarra-Carmona, A.E. and A. Pantoja. 1988a. Evaluation of relative sampling methods for population estimation of the pepper weevil, Anthonomus eugenii Cano (Coleoptera: Curculionidae). Journal of Agriculture, University of Puerto Rico 72:387-393. 
Segarra-Carmona AE, Pantoja A. 1988b.

Sequential sampling plan, yield loss components and economic thresholds for the pepper weevil,

Anthonomus eugenii Cano (Coleoptera:

Curculionidae). Journal of Agriculture, University of Puerto Rico 72:375-385.

Toapanta MA. 2001. Population ecology, life history, and biological control of the pepper weevil, Anthonomus eugenii Cano (Coleoptera: Curculionidae) Unpublished Ph.D. dissertation, University of Florida, Gainesville. 152 pp. 